\title{
Opuntia Fruits as Food Enriching Ingredient, the First Step towards New Functional Food Products
}

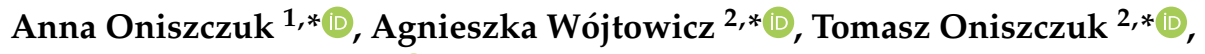 \\ Arkadiusz Matwijczuk ${ }^{3}$ D, Ahlem Dib $^{4}$ and Ewa Markut-Miotła 5 \\ 1 Department of Inorganic Chemistry, Medical University of Lublin, Chodźki 4a, 20-093 Lublin, Poland \\ 2 Department of Thermal Technology and Food Process Engineering, University of Life Sciences in Lublin, \\ Głęboka 31, 20-612 Lublin, Poland \\ 3 Department of Biophysics, University of Life Sciences in Lublin, Akademicka 13, 20-950 Lublin, Poland; \\ arkadiusz.matwijczuk@up.lublin.pl \\ 4 Laboratoire de Nutrition et Technologie Alimentaire, Institut de la Nutrition, de l'Alimentation et des \\ Technologies Agro-Alimentaires, Université des Frères Mentouri, Constantine 25017, Algeria; \\ ahlemlabo@yahoo.fr \\ 5 Departament of Lung Diseases \& Rheumatology, Medical University of Lublin, 20-093 Lublin, Poland; \\ ewa.markut-miotla@umlub.pl \\ * Correspondence: anoniszczuk@o2.pl (A.O.); agnieszka.wojtowicz@up.lublin.pl (A.W.); \\ tomasz.oniszczuk@up.lublin.pl (T.O.); Tel.: +48-81448-7160 (A.O.)
}

Received: 6 February 2020; Accepted: 14 February 2020; Published: 18 February 2020

\begin{abstract}
Prickly pear (Opuntia ficus indica (L.) Mill.) is a rich source of vitamins C, $\mathrm{B}_{1}, \mathrm{~B}_{2}$, A, and $\mathrm{E}$, minerals such as calcium, potassium, magnesium, iron, and phosphorus, as well as bioactive substances, i.e., carotenoids, betalains, and phenolic compounds. Of these, the phenolic acids, betalains, and flavonoids are notable in that they are largely responsible for the health-promoting properties of this plant. The purpose of the presented research was to first determine the antioxidant properties and the content of polyphenolic compounds (including individual phenolic acids) in prickly pear fruit, then to produce an innovative gluten-free pasta from rice-field bean flour enriched with various amounts of pear prickly fruit. The content of free phenolic acids, the sum of polyphenols and antioxidant properties of pasta were subsequently determined in the supplemented pasta. Chromatographic analysis (HPLC-ESI-MS/MS) showed a wide variety of phenolic acids. In the fruit sample, 14 acids were detected, whereas in the pasta sample without additives, 9. The dominant acid was isoferulic. The total content of free phenolic acids and the sum of polyphenols increased with increasing content of the functional additive. Moreover, the content of individual acids generally increased as the Opuntia fruit was added. The antioxidant activity was also positively correlated with the addition of fruit, with the content of free phenolic acids and the sum of polyphenols. Our research has shown that our innovative pasta with the addition of prickly fruit can become a source of the free phenolic acids indispensable for human health.
\end{abstract}

Keywords: Opuntia ficus indica (L.) Mill.; liquid chromatography; functional food; gluten-free pasta; antioxidant activity; phenolic acids

\section{Introduction}

Opuntia fig (Opuntia ficus indica (L.) Mill.), otherwise known as the Indian fig or cactus fig or prickly pear, belongs to the Cactus family, Cactaceae. These species hold high adaptability to extreme environmental conditions (drought, high temperature, UV radiation, and poor-quality soils). Originally from Mexico, it is grown in many warm climate (mainly tropical or subtropical) areas, and its fruits, flowers, and leaves are edible. 
The fruits of prickly pear probably first reached Europe by way of the expedition of Christopher Columbus, hence the name ficus-indica. In countries with limited water resources, this plant is an excellent raw material for farm-based industries and has high nutritional, medicinal, and industrial value.

Indian fig is one of the most widely cultivated cacti in the world [1-3]. The fruits of Opuntia contain a lot of water, about $93 \%$ of fresh mass, while the main components of the dry matter are sugars: glucose and fructose, as well as dietary fibers (about $50 \%$ of the dry mass). The fat content is negligible, and the protein is about $13 \% \mathrm{~d} . \mathrm{m}$. The fruits are also a rich source of vitamins $C, B_{1}$, $\mathrm{B}_{2}, \mathrm{~A}$, and $\mathrm{E}$, minerals, such as calcium, potassium, magnesium, iron, and phosphorus, as well as bioactive substances, i.e., carotenoids and phenolic compounds. Of the polyphenols, phenolic acids, anthocyanin, and flavonoid content is notable [1,4-6]. The peel and pulp are characterized by their held antioxidant power, due to the polyphenols, flavonoids, and betalains content $[7,8]$. Betalains present in the epidermis and the pulp of the prickly pear confers on it its color varying from yellow to purple (for example, betacyanins: red and blue and betaxanthines: yellow and orange). Those pigments are by-products of betalamic acid [8].

Because of their high organoleptic attractiveness and high sugar content, the fruits are eaten in both in raw and processed forms. Furthermore, the leaves (cladode) in Mexican cuisine are treated as a cooked or fired vegetable [5], and consumption generates significant reductions in serum glucose and insulin, indicating potential as a functional food candidate [9]. In addition, it should be noted that in Mexican and Chinese folk medicine, the pear pulp is used to accelerate the healing of wounds and ulcers, to treat gastrointestinal complaints, diabetes, and atherosclerosis. Studies have also confirmed its effectiveness in hyperglycemia and hypercholesterolemia. These effects are mainly associated with its held antioxidant properties [4]. The pulp also stimulates the pancreas to secrete insulin, and the fiber contained in the fruit reduces the level of LDL cholesterol. The fruit, even when eaten in small quantities, gives a feeling of fullness. This effect promotes weight reduction. Hence, the consumption of cactus pear has a positive effect on body weight and cardiovascular risk factors [10]. What is more, in unfavorable environmental conditions, Opuntia G, a substance that protects the pulp, is produced in the fruit. If applied to the skin, it increases its resistance to UV radiation, Indian fig is, therefore, utilized in anti-wrinkle formulations, stimulating skin renewal, and moisturizing [5].

Due to the high nutritional value of Opuntia, it is juiced [11-13], produced as an essential oil and a gum [14], transformed into alcohol [15], or used as a food additive [16].

Some studies report the enrichment of durum wheat pasta with 3\% of Opuntia cladode. This serves as a source of polysaccharides, as well as phytochemical compounds, such as phenolic acids and flavonoids [17]. Indeed, Aiello et al. [17] found that pasta with 3\% of Opuntia cladode extract is a functional food for the prevention of age-related metabolic disorders, hyperglycemia, and for maintaining normal weight.

As wheat-based pasta cannot be consumed by those with coeliac disease or gluten intolerance, gluten-free products need to be developed. As such items are usually poor nutritionally, their value must be increased through supplementation with fruits, vegetables, legumes, or herbs, ether as fresh and dried products or plant extracts.

The purpose of the presented research was, firstly, to determine the antioxidant properties and the content of polyphenolic compounds (including individual phenolic acids) in prickly pear fruit, secondly, to produce an innovative gluten-free pasta from rice-field bean flour that has been enriched with various amounts of Opuntia fruits. This was then analyzed to determine its content of free phenolic acids, its antioxidant properties, and the sum of its polyphenols. 


\section{Materials and Methods}

\subsection{Chemicals}

Acetonitrile and formic acid requested for chromatographic analysis, ethanol for extraction and Folin-Ciocalteu reagent were purchased from J.T. Baker (Phillipsburg, NJ, USA). The used standards and DPPH (2,2-diphenyl-1-picrylhydrazyl) were provided by Sigma Aldrich (St. Louis, MO, USA). Water was purified on a MilliQ system (Millipore S.A., Molsheim, France).

\subsection{Pasta Preparation}

Fruits of Opuntia ficus indica (L.) Mill (yellow and orange) were brought from the local Algerian market. Fruits were washed and air dried at $40{ }^{\circ} \mathrm{C}$ overnight. The peel and seeds were separated manually from the pulp. Samples were chopped into small pieces, homogenized with an automatic press and dehydrated in a convection oven at $50^{\circ} \mathrm{C}$ for $8-9 \mathrm{~h}$. The dehydrated samples were ground in a hammer mill fitted with a $2 \mathrm{~mm}$ round orifice screen.

Gluten-free pasta was prepared on the base of rice flour and field bean flour blends at 2:1 ratio by mass (control sample). To bind together the gluten-free components, part of the rice flour was gelatinized by mixing with water $1: 9(w / w)$ and heated and stirred on a heating plate for 8-9 min until the temperature of $65^{\circ} \mathrm{C}$ was reached. The prepared mixture was cooled down by being held for $1 \mathrm{~h}$ at room temperature and then kept in a fridge at $4^{\circ} \mathrm{C}$ for $24 \mathrm{~h}$. After storage, the gelatinized flour was seasoned by being held for $1 \mathrm{~h}$ at room temperature and was then added to the basic pasta recipe in an amount of 1:2 (w/w). The basic blend was supplemented with the addition of dried Opuntia fruits in amounts of $2.5 \%, 5.0 \%, 7.5 \%, 10.0 \%, 12.5 \%$, and $15.0 \%(w / w)$. All the components were mixed for $15 \mathrm{~min}$ at $25{ }^{\circ} \mathrm{C}$, using a KitchenAid mixer (model kPM5, St. Joseph, MI, USA) then the dough was molded and passed through the reduction rolls of a pasta machine Marcato Ampia type 150 (Campodarsego, Italy) for a uniform dough sheet and subsequently cut to the tagliatelle shape with noodles being of $5 \mathrm{~mm}$ width, $1.5 \mathrm{~mm}$ thick, and $50 \mathrm{~mm}$ length. Finally, the pasta samples were dried in an air oven at $40{ }^{\circ} \mathrm{C}$ for $4 \mathrm{~h}$ until they reached a final moisture content below $12 \%$. The pasta was then ground and stored in sealed plastic bags at room temperature.

\subsection{Preparation of Extracts}

Opuntia fruit (2-gramportion), as well as supplemented pasta samples, were prepared and mixed with $40 \mathrm{~mL}$ of $80 \%$ ethanol. The extraction process was performed in an ultrasonic bath with a thermostat (BANDELIN electronic GmbH \& Co. KG, Berlin, Germany) for 40 min at a temperature of $60{ }^{\circ} \mathrm{C}$, ultrasound frequency of $33 \mathrm{kHz}$ and a power of $320 \mathrm{~W}$. The extracts were filtered, and $40 \mathrm{~mL}$ of $80 \%$ ethanol was added to the reminder to repeat the extraction. The obtained extractions were blended and evaporated. The dry residues were quantitatively transferred to volumetric flasks and supplemented with methanol up to $5 \mathrm{~mL}$ [18-20].

\subsection{LC-ESI-MS/MS Analysis of Phenolic Acids}

Phenolic acid content was determined according to a modified method described by Oniszczuk et al. [21]. Experiments were carried out using an Agilent 1200 Series HPLC system (Agilent Technologies, Santa Clara, CA, USA) connected to a 3200 QTRAP Mass spectrometer (AB Sciex, Redwood City, CA, USA) equipped with electrospray ionization source (ESI). Both were controlled with Analyst 1.5 software (AB Sciex, USA). This was also used for data interpretation. Separations were carried out on a Zorbax SB-C18 column $(2.1 \times 100 \mathrm{~mm}, 1.8-\mu \mathrm{m}$ particle size; Agilent Technologies, Santa Clara, CA, USA) at $20^{\circ} \mathrm{C}$. The gradient method was used with mobile phases: Water with $0.1 \%$ $\mathrm{HCOOH}(\mathrm{A})$ and acetonitrile with $0.1 \% \mathrm{HCOOH}(\mathrm{B})$. Herein, the injection volume was $3 \mu \mathrm{L}$, the flow rate was $250 \mu \mathrm{L} / \mathrm{min}$ and the gradient were as follows: $0-2 \mathrm{~min}: 25 \% \mathrm{~B}, 3-6 \mathrm{~min}$ : 35\% $\mathrm{B}, 8-10 \mathrm{~min}$ : 55\% B, 12-16 min: 75\% B, 19-25 min: 25\% B. ESI operated in the negative-ion mode at the following conditions: Capillary temperature $400{ }^{\circ} \mathrm{C}$, curtain gas at $30 \mathrm{psi}$, nebulizer gas at 50 psi, negative 
ionization mode source voltage $-4500 \mathrm{~V}$. Triplicate injections were made for each standard solution and sample. The analytes were identified by comparing retention time and $m / z$ values obtained by MS and MS2 with the mass spectra from corresponding standards tested under the same conditions. The identified phenolic acids were quantified based on their peak areas and by comparison with a calibration curve obtained via the corresponding standards.

\subsection{Determination of the Total Content of Polyphenolic Compounds}

The total content of polyphenolic compounds was determined utilizing the modified Folin-Ciocalteu (FC) method [21,22]. Here, $900 \mu \mathrm{L}$ of distilled water and $100 \mu \mathrm{L}$ of Folin-Ciocalteu reagent were added to $100 \mu \mathrm{L}$ of the tested extracts. The solutions were mixed and put aside. After $4 \mathrm{~min}, 1 \mathrm{~mL}$ of $7.7 \%$ sodium bicarbonate and $400 \mu \mathrm{L}$ of distilled water were added. The content was mixed and placed in a water bath $\left(40^{\circ} \mathrm{C}\right)$ for $50 \mathrm{~min}$. After this, the absorbance of the solutions was measured using a UV-VIS spectrometer (Genesys 10S UV-VIS, Thermo Scientific, Waltham, MA, USA) at a wavelength of $765 \mathrm{~nm}$. The calibration curve of gallic acid was then plotted. For this purpose, $100 \mu \mathrm{L}$ of each of the calibration solutions was collected, while $900 \mu \mathrm{L}$ of distilled water and $100 \mu \mathrm{L}$ of Folin-Ciocalteu reagent were added and processed following the same procedure as for the extracts above. A solution without gallic acid was used for the blank experiment. The total content of polyphenols in the tested extracts was expressed as gallic acid equivalents (GAE).

\subsection{Radical Scavenging Assay}

The antioxidative capacity of the tested extracts was measured using a $0.1 \mathrm{mM}$ methanol solution of the DPPH stable radical (2,2-diphenyl-1-picrylhydrazyl). Absorbance was measured at $517 \mathrm{~nm}$ wavelength, and the UV-VIS spectrophotometer was calibrated to pure methanol. In the following step, absorbance of the samples containing $2.5 \mathrm{~mL}$ of DPPH solution and $0.5 \mathrm{~mL}$ of the extract was assessed. The measurements were carried out every $5 \mathrm{~min}$ for $30 \mathrm{~min}$ [22]. Based on the results, the free radical scavenging ability of the tested extracts was calculated using the following formula:

$$
\% \mathrm{RSA}=[(A 0-A 1) / A 0] \times 100,
$$

where: $A 0$ is the absorbance of the sample except tested extracts, $A 1$ is the absorbance of the sample with tested extracts.

Standard antioxidant, gallic acid $(0.25 \mathrm{mg} / \mathrm{mL})$ was used as a positive control. Gallic acid proceeded by the same way as tested extracts.

\subsection{Statistical Analysis}

All the measurements were done in three replications. Results were mean values of multiple repetitions \pm standard deviation (SD). Statistical analysis with ANOVA (Statistica 13.0, StatSoft Inc., Tulsa, OK, USA) was used to determine the significance of differences at $\alpha=0.05$ with Duncan's test to evaluate the homogenous groups. Pearson's correlation coefficients and their significance were evaluated at 0.05 and 0.01 for the tested characteristics.

\section{Results and Discussion}

\subsection{Composition of Dried Opuntia Extracts}

Polyphenol compounds are a widespread group of secondary metabolites, and many desirable biological effects depend on their presence in consumed plants. In the first stage of the study, the total content of ethanol polyphenols extracts from prickly pear fruit was examined. The technique employed to obtain extracts was a 40-min ultrasonic-assisted extraction at an elevated temperature using an $80 \%$ aqueous ethanol solution. This method was chosen because, in previously conducted experiments, this turned out to be optimal for isolating phenolic compounds from plant material [21]. 
In our work, the total polyphenol content was high and reached $14.948 \mathrm{mg}$ GAE/g of dry matter. The results obtained are consistent with the research carried out by Yeddes et al. [7] who, when testing different species of prickly pear, revealed that this plant is rich in polyphenols. They also demonstrated the high antioxidant potential of Opuntia fruit extracts in DPPH test. This research is compatible with the results of Moussa-Ayoub et al. [23], who showed that the O. ficus indica peel and pulp demonstrated a high ability to scavenge free radicals. They explained their results by the presence of large amounts of flavonols, phenolics, as well as betacyanins in the fruit's peel and pulp. Maataoui et al. [24] showed that the purple juice of the $O$. ficus indica has a higher antioxidant activity than the yellow-orange juice. In line with their work, in our experiment, the prickly fruit showed high potential of DPPH free radical scavenging, herein, equaling 99.78\% (Table 1).

Table 1. Radical scavenging activity of gluten-free pasta samples depend on time and Opuntia fruit addition ( $\mathrm{n}=3$ mean $\pm \mathrm{SD})$.

\begin{tabular}{|c|c|c|c|c|c|c|c|c|c|}
\hline \multicolumn{9}{|c|}{ Radical Scavenging towards DPPH (\%) } & \multirow[b]{3}{*}{$\begin{array}{l}\text { Gallic } \\
\text { Acid }\end{array}$} \\
\hline \multirow{2}{*}{$\begin{array}{l}\text { Time } \\
\text { (min) }\end{array}$} & \multicolumn{7}{|c|}{ Addition of Opuntia (\%) } & \multirow[b]{2}{*}{$\begin{array}{c}\text { Opuntia } \\
\text { Fruit }\end{array}$} & \\
\hline & 0 & 2.5 & 5.0 & 7.5 & 10.0 & 12.5 & 15.0 & & \\
\hline 0 & $\begin{array}{l}18.25^{\mathrm{a}} \\
\pm 0.22\end{array}$ & $\begin{array}{l}13.57^{b} \\
\pm 0.05\end{array}$ & $\begin{array}{l}14.69^{b} \\
\pm 0.10\end{array}$ & $\begin{array}{c}17.92^{b, c} \\
\pm 0.06\end{array}$ & $\begin{array}{l}22.18^{c} \\
\pm 0.68\end{array}$ & $\begin{array}{c}33.37^{\mathrm{d}} \\
\pm 0.89\end{array}$ & $\begin{array}{c}33.37^{\mathrm{d}} \\
\pm 0.01\end{array}$ & $\begin{array}{c}35.38^{\mathrm{e}} \\
\pm 0.01\end{array}$ & $\begin{array}{l}99.37^{\mathrm{c}} \\
\pm 0.01\end{array}$ \\
\hline 5 & $\begin{array}{c}82.75^{a} \\
\pm 0.33\end{array}$ & $\begin{array}{l}93.95^{b} \\
\pm 1.32\end{array}$ & $\begin{array}{c}93.95^{b} \\
\pm 1.21\end{array}$ & $\begin{array}{c}94.67^{b, c} \\
\pm 0.59\end{array}$ & $\begin{array}{c}94.26^{b, c} \\
\pm 1.32\end{array}$ & $\begin{array}{l}96.03^{\mathrm{c}} \\
\pm 0.01\end{array}$ & $\begin{array}{c}94.92 \mathrm{~b}, \mathrm{c} \\
\pm 0.04\end{array}$ & $\begin{array}{l}96.88^{c} \\
\pm 0.56\end{array}$ & $\begin{array}{c}100.00^{b, c} \\
\pm 0.00\end{array}$ \\
\hline 10 & $\begin{array}{c}83.02^{a} \\
\pm 0.01\end{array}$ & $\begin{array}{c}93.95^{b} \\
\pm 0.67\end{array}$ & $\begin{array}{c}94.52 \mathrm{~b}, \mathrm{c} \\
\pm 0.11\end{array}$ & $\begin{array}{l}95.16^{c} \\
\pm 0.21\end{array}$ & $\begin{array}{c}95.76^{c} \\
\pm 0.03\end{array}$ & $\begin{array}{c}96.23^{\mathrm{c}, \mathrm{d}} \\
\pm 0.02\end{array}$ & $\begin{array}{l}97.04^{\mathrm{d}} \\
\pm 0.33\end{array}$ & $\begin{array}{l}99.78^{\mathrm{e}} \\
\pm 0.23\end{array}$ & $\begin{array}{c}100.00^{c} \\
\pm 0.00\end{array}$ \\
\hline 15 & $\begin{array}{l}83.02^{a} \\
\pm 0.02\end{array}$ & $\begin{array}{l}93.95^{b} \\
\pm 0.01\end{array}$ & $\begin{array}{c}94.52^{b, c} \\
\pm 0.00\end{array}$ & $\begin{array}{l}95.16^{c} \\
\pm 0.03\end{array}$ & $\begin{array}{l}95.76^{\mathrm{c}} \\
\pm 0.00\end{array}$ & $\begin{array}{c}96.23^{c, d} \\
\pm 0.03\end{array}$ & $\begin{array}{c}97.04^{\mathrm{d}} \\
\pm 0.00\end{array}$ & $\begin{array}{l}99.78^{\mathrm{e}} \\
\pm 0.03\end{array}$ & $\begin{array}{c}100.00^{b, c} \\
\pm 0.00\end{array}$ \\
\hline 20 & $\begin{array}{c}83.02^{\mathrm{a}} \\
\pm 0.00\end{array}$ & $\begin{array}{c}93.95^{b} \\
\pm 0.01\end{array}$ & $\begin{array}{c}94.52^{b, c} \\
\pm 0.02\end{array}$ & $\begin{array}{c}95.16^{c} \\
\pm 0.01\end{array}$ & $\begin{array}{c}95.76^{c} \\
\pm 0.03\end{array}$ & $\begin{array}{c}96.23^{\mathrm{c}, \mathrm{d}} \\
\pm 0.01\end{array}$ & $\begin{array}{c}97.04^{d} \\
\pm 0.00\end{array}$ & $\begin{array}{c}99.78^{\mathrm{e}} \\
\pm 0.00\end{array}$ & $\begin{array}{c}100.00^{b, c} \\
\pm 0.00\end{array}$ \\
\hline
\end{tabular}

The next step was the qualitative and quantitative analysis of the content of phenolic acids carried out by way of high-performance liquid chromatography, coupled with mass spectrometry (HPLC-ESI-MS/MS). Chromatographic analysis showed that a large variety of phenolic acids are present in the prickly fruit. Indeed, up to 14 phenolic acids were detected (Figure 1, Table 2). These were mostly benzoic acid derivatives: protocatechuic, syryngic, 4-OH-benzoic, vanilic, gentisic, salicylic, and cinnamic acid derivatives: caffeic, trans-sinapic and cis-sinapic, $p$-coumaric, ferulic, isoferulic, $m$-coumaric, and 3,4-dimetoxycinnamic. The total content of free phenolic acids reached a value of $57.957 \mu \mathrm{g} / \mathrm{g}$ of dry matter. Isoferulic acid, which is dominant in the prickly pear fruit, is an effective natural antioxidant in both the lipid and aquatic environment [25]. The results of the research showed that the prickly pear fruit is a great source of free phenolic acids. These are natural antioxidants, and the consumption of foods with a high content of phenolic acids has important health benefits due to their anti-cancer, anti-bacterial, and anti-inflammatory properties.

Because of the high antioxidant potential and high polyphenolic compound content, the authors designed a gluten-free food product enriched with different percentages of prickly pear. In this way, pasta was created, the basic recipe of which was rice flour and field bean flour blend in the amount of 2:1. As an addition to the basic recipe, dried Opuntia fruit was used in the amount of $2.5 \%, 5.0 \%$, $7.5 \%, 10.0 \%, 12 \%$, and $15.0 \%$. The pasta was subsequently tested for the antioxidant properties and the polyphenols content. 

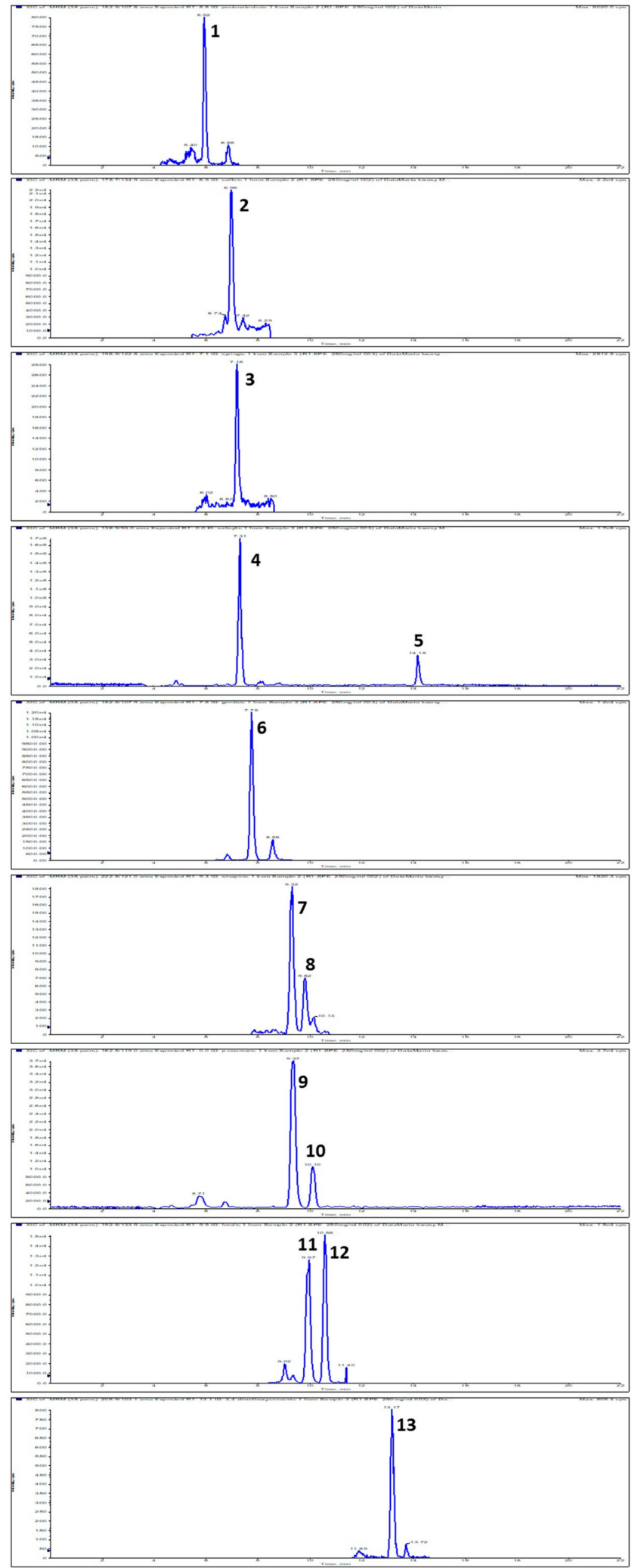

Figure 1. Extracted LC-MS-MRM chromatogram of phenolic acids found in prickly pear. MRM transition are given in brackets: 1 , protocatechuic $(\mathrm{m} / \mathrm{z} 152.9 \rightarrow 107.8) ; 2$, caffeic $(\mathrm{m} / \mathrm{z} 178.7 \rightarrow 134.9) ; 3$, syringic acid (m/z $196.9 \rightarrow 122.8) ; 4$, 4-hydroxy-benzoic $(\mathrm{m} / \mathrm{z} 136.9 \rightarrow 93) ; 5$, salicylic $(\mathrm{m} / \mathrm{z} 136.9 \rightarrow 93)$; 6 , gentisic (m/z 152.8 $\rightarrow$ 107.9); 7, trans-sinapic acid (m/z $222.8 \rightarrow 148.9) ; 8$, cis-sinapic acid (m/z $222.8 \rightarrow$ $148.9) ; 9, p$-coumaric $(\mathrm{m} / \mathrm{z} 162.8 \rightarrow 119) ; 10$, m-coumaric $(\mathrm{m} / \mathrm{z} 162.8 \rightarrow 119) ; 11$, ferulic $(\mathrm{m} / \mathrm{z} 192.8 \rightarrow$ 133.9); 12, isoferulic acid (m/z m/z $192.8 \rightarrow 133.9) ; 13$, 3,4-dimethoxycinnamic acid (m/z 206.8 $\rightarrow$ 147.9). 
Table 2. Content of phenolic acids in Opuntia fruit and gluten-free pasta samples enriched with Opuntia fruit addition ( $\mathrm{n}=3$; mean \pm SD).

\begin{tabular}{|c|c|c|c|c|c|c|c|c|c|c|c|c|c|c|c|}
\hline \multirow{2}{*}{$\begin{array}{l}\text { Addition of } \\
\text { Opuntia }(\%)\end{array}$} & \multicolumn{15}{|c|}{ Content of Phenolic Acids $(\mu \mathrm{g} / \mathrm{g})$} \\
\hline & Protocatechuic & Caffeic & Syryngic & 4-OH-Benzoic & Vanilic & Gentisic & $\begin{array}{c}\text { trans- } \\
\text { Sinapic }\end{array}$ & $\begin{array}{c}c i s- \\
\text { Sinapic }\end{array}$ & $p$-Coumaric & Ferulic & Isoferulic & $m$-Coumaric & 3,4-Dimetoxycinnamic & Salicylic & Sum \\
\hline Opuntia fruit & $0.616^{\mathrm{d}} \pm 0.008$ & $\begin{array}{c}0.404 \\
\pm 0.002\end{array}$ & $\begin{array}{c}1.552 \\
\pm 0.043\end{array}$ & $\begin{array}{l}3.558^{d} \\
\pm 0.038\end{array}$ & BQL & $\begin{array}{l}0.196^{\mathrm{d}} \\
\pm 0.005\end{array}$ & $\begin{array}{c}1.025 \\
\pm 0.003\end{array}$ & $\begin{array}{c}0.042 \\
\pm 0.0001\end{array}$ & $\begin{array}{l}1.680^{\mathrm{d}} \\
\pm 0.011\end{array}$ & $\begin{array}{l}4.160^{\mathrm{e}} \\
\pm 0.105\end{array}$ & $\begin{array}{l}43.223^{\mathrm{e}} \\
\pm 0.345\end{array}$ & $\begin{array}{l}0.252^{\mathrm{ab}} \\
\pm 0.001\end{array}$ & $\begin{array}{l}0.724^{\mathrm{d}} \\
\pm 0.008\end{array}$ & $\begin{array}{l}0.515^{\mathrm{a}} \\
\pm 0.009\end{array}$ & 57.957 \\
\hline 0 & $0.087^{\mathrm{a}} \pm 0.002$ & $\mathrm{ND}$ & $\mathrm{ND}$ & $\begin{array}{l}1.046^{\mathrm{a}} \\
\pm 0.019\end{array}$ & ND & $\begin{array}{c}0.035^{\mathrm{a}} \\
\pm 0.0002\end{array}$ & $\mathrm{ND}$ & ND & $\begin{array}{l}0.252^{\mathrm{a}} \\
\pm 0.008\end{array}$ & $\begin{array}{l}0.393^{\mathrm{a}} \\
\pm 0.013\end{array}$ & $\begin{array}{l}23.124^{\mathrm{a}} \\
\pm 0.2052\end{array}$ & $\begin{array}{l}0.268^{\mathrm{b}} \\
\pm 0.001\end{array}$ & $\begin{array}{l}0.252^{\mathrm{a}} \\
\pm 0.014\end{array}$ & $\begin{array}{l}1.214^{\mathrm{d}} \\
\pm 0.022\end{array}$ & 26.671 \\
\hline 2.5 & $0.093^{\mathrm{a}} \pm 0.003$ & ND & $\mathrm{ND}$ & $\begin{array}{l}1.492^{\mathrm{ab}} \\
\pm 0.043\end{array}$ & ND & $\begin{array}{c}0.040^{\mathrm{ab}} \\
\pm 0.0000\end{array}$ & ND & ND & $\begin{array}{l}0.278^{\mathrm{a}} \\
\pm 0.003\end{array}$ & $\begin{array}{c}0.408^{\mathrm{a}} \\
\pm 0.008\end{array}$ & $\begin{array}{c}24.416^{\mathrm{ab}} \\
\pm 0.012\end{array}$ & $\begin{array}{c}0.247^{\mathrm{a}} \\
\pm 0.012\end{array}$ & $\begin{array}{l}0.265^{\mathrm{a}} \\
\pm 0.005\end{array}$ & $\begin{array}{l}1.120^{\mathrm{cd}} \\
\pm 0.021\end{array}$ & 28.359 \\
\hline 5.0 & $0.112^{\mathrm{ab}} \pm 0.003$ & ND & ND & $\begin{array}{l}1.612^{\mathrm{b}} \\
\pm 0.051\end{array}$ & ND & $\begin{array}{c}0.046^{\mathrm{b}} \\
\pm 0.0000\end{array}$ & ND & ND & $\begin{array}{l}0.307^{\mathrm{ab}} \\
\pm 0.001\end{array}$ & $\begin{array}{l}0.409^{\mathrm{a}} \\
\pm 0.012\end{array}$ & $\begin{array}{l}25.636^{\mathrm{b}} \\
\pm 0.018\end{array}$ & $\begin{array}{l}0.258^{\mathrm{ab}} \\
\pm 0.012\end{array}$ & $\begin{array}{l}0.277^{\mathrm{ab}} \\
\pm 0.010\end{array}$ & $\begin{array}{l}0.86^{c} \\
\pm 0.031\end{array}$ & 29.525 \\
\hline 7.5 & $0.184^{\mathrm{b}} \pm 0.004$ & ND & ND & $\begin{array}{l}2.316^{\mathrm{bc}} \\
\pm 0.033\end{array}$ & ND & $\begin{array}{c}0.051^{\mathrm{b}} \\
\pm 0.0001\end{array}$ & ND & ND & $\begin{array}{l}0.358^{\mathrm{b}} \\
\pm 0.012\end{array}$ & $\begin{array}{l}0.557^{\mathrm{ab}} \\
\pm 0.014\end{array}$ & $\begin{array}{c}27.677^{\mathrm{bc}} \\
\pm 0.122\end{array}$ & $\begin{array}{l}0.240^{\mathrm{a}} \\
\pm 0.011\end{array}$ & $\begin{array}{l}0.292^{\mathrm{b}} \\
\pm 0.001\end{array}$ & $\begin{array}{l}0.828^{\mathrm{bc}} \\
\pm 0.029\end{array}$ & 32.503 \\
\hline 10 & $0.192^{b} \pm 0.006$ & ND & ND & $\begin{array}{c}2.644^{c} \\
\pm 0.024\end{array}$ & ND & $\begin{array}{l}0.057^{\mathrm{bc}} \\
\pm 0.0002\end{array}$ & ND & ND & $\begin{array}{l}0.420^{\mathrm{bc}} \\
\pm 0.024\end{array}$ & $\begin{array}{l}0.735^{\mathrm{b}} \\
\pm 0.032\end{array}$ & $\begin{array}{l}28.751^{\mathrm{c}} \\
\pm 0.030\end{array}$ & $\begin{array}{l}0.266^{\mathrm{b}} \\
\pm 0.007\end{array}$ & $\begin{array}{l}0.316^{\mathrm{b}} \\
\pm 0.000\end{array}$ & $\begin{array}{l}0.716^{\mathrm{b}} \\
\pm 0.001\end{array}$ & 34.097 \\
\hline 12.5 & $0.242^{\mathrm{bc}} \pm 0.007$ & ND & ND & $\begin{array}{l}2.720^{c} \\
\pm 0.038\end{array}$ & ND & $\begin{array}{c}0.061^{c} \\
\pm 0.0003\end{array}$ & ND & ND & $\begin{array}{l}0.486^{\mathrm{bc}} \\
\pm 0.007\end{array}$ & $\begin{array}{c}0.992^{\mathrm{c}} \\
\pm 0.027\end{array}$ & $\begin{array}{c}30.428^{\mathrm{cd}} \\
\pm 0.424\end{array}$ & $\begin{array}{l}0.246^{\mathrm{a}} \\
\pm 0.006\end{array}$ & $\begin{array}{l}0.336^{\mathrm{bc}} \\
\pm 0.008\end{array}$ & $\begin{array}{l}0.642^{\mathrm{ab}} \\
\pm 0.018\end{array}$ & 36.153 \\
\hline 15.0 & $0.344^{\complement} \pm 0.005$ & ND & ND & $\begin{array}{l}2.856^{c} \\
\pm 0.132\end{array}$ & ND & $\begin{array}{c}0.063^{c} \\
\pm 0.0001\end{array}$ & ND & ND & $\begin{array}{l}0.536^{c} \\
\pm 0.006\end{array}$ & $\begin{array}{l}1.544^{\mathrm{d}} \\
\pm 0.065\end{array}$ & $\begin{array}{l}32.321^{\mathrm{d}} \\
\pm 0.692\end{array}$ & $\begin{array}{l}0.258^{\mathrm{ab}} \\
\pm 0.006\end{array}$ & $\begin{array}{l}0.362^{\mathrm{c}} \\
\pm 0.006\end{array}$ & $\begin{array}{l}0.638^{\mathrm{ab}} \\
\pm 0.013\end{array}$ & 38.876 \\
\hline
\end{tabular}

a-e similar letters in columns indicate insignificant differences at $\alpha=0.05$. 


\subsection{Results of Analysis of Extracts from Pasta Enriched with Different Percentages of Opuntia Fruits}

In the assessment of the total content of polyphenols in the pasta blends, the results clearly showed that the polyphenol content increased along with the increase of prickly pear fruit content. Herein, the sum of polyphenols reached 4.641, 4.983, 5.447, 5.672, 6.068, and 6.367 and $6.528 \mathrm{mg}$ GAE/g dry matter for the control and enriched samples at $2.5 \%, 5.0 \%, 7.5 \%, 10.0 \%, 12.5 \%$, and $15.0 \%$ of prickly pear fruit, respectively.

On establishing the antiradical scavenging ability of pasta supplemented with Opuntia fruit, the antioxidant properties of the tested pasta in relation to the DPPH free radical were also high. The percentage of DPPH scavenging was 83.02, 93.95, 94.52, 95.16, 95.76, 96.23, and 97.04 for samples containing $0 \%, 2.5 \%, 5.0 \%, 7.5 \%, 10.0 \%, 12.5 \%$, and $15.0 \%$ of Opuntia fruit, respectively (Table 1 ). The test confirmed that the increased amount of prickly pear in the pasta, enhanced concurrently their antioxidant properties. Thus, we observed that an increase in the amount of functional additive brought about an increase in polyphenol content and an increase in antioxidant properties. The scavenging capacity against DPPH radicals was positively correlated with total polyphenols content and with the free phenolic acids content at $\alpha=0.05$ (Table 3).

Table 3. Pearson's correlation coefficients for gluten-free pasta supplemented with Opuntia fruit addition.

\begin{tabular}{cccc}
\hline & Total Polyphenols & Free Phenolic Acid & DPPH Radical Scavenging Activity \\
\hline Opuntia fruit content & $0.994^{* *}$ & $0.995^{* *}$ & $0.768^{*}$ \\
Total polyphenols & & $0.979^{* *}$ & $0.795^{*}$ \\
Free phenolic acids & & & $0.729^{*}$ \\
\hline
\end{tabular}

${ }^{*}$ significant at $\alpha=0.05,{ }^{* *}$ significant at $\alpha=0.01$.

The maximum scavenging ability of free radicals by all extracts was obtained after $10 \mathrm{~min}$. As previously reported by Kuti [26] and Gentile et al. [27], the beneficial effect on the human body brought about by consumption of prickly pear is largely due to their antioxidant properties resulting from the content of polyphenol compounds. Moreover, the content of individual phenolic acids increased as the amount of prickly fruit increased. The exception was salicylic acid, the content of which steadily decreased and reached the lowest value in the sample enriched with $15.0 \%$ of the additive. This is conditioned by the fact that the basis pasta, i.e., a mixture of rice and field bean flour, is richer in this acid than the prickly pear fruit. It is, therefore, understandable that as the dried Opuntia was added, the amount of this component was reduced. Furthermore, the content of $m$-coumaric acid remained the same in all samples.

Phenolic compounds are secondary metabolites in plants so they can be variously distributed in the structure of plants, e.g., insoluble phenolics in cell walls, but soluble phenols within vacuoles of vegetable cells. Therefore, in various parts of plants (fruits, flowers, leaves) there can be different distribution and concentration of phenolic compounds [28]. Moreover, variations in phenol concentration during food processing or drying may be due to the early degradation of phenolic compounds favored by high temperatures and prolonged exposure to heat due to the release of phenolic substances caused by the rupture of the ether, ester, or acetal covalent bonds [29]. Thermal degradation may occur at the same time that the phenolic substances are released, but its concentration may be observed when maximal degradation is reached at the temperatures evaluated [30]. It is especially visible at high-temperature treatment, as reported by Mutari et al. [31], who suggest that higher temperatures can improve the solubility of phenolic compounds leading to the breakdown of cellular structures and improving the release of phenolic compounds, such phenolic acids (ferulic, galic, and vanillic acid), previously bound to the macromolecules of the cell wall. Moreover, processing can accelerate the release of phenolic compounds due to the breaking of cellular constituents. Drying in low temperature $\left(40{ }^{\circ} \mathrm{C}\right.$ and $50{ }^{\circ} \mathrm{C}$ in our experiment) is not sufficiently high to deactivate hydrolytic or oxidative enzymes which may have an influence on phenolic content in tested materials [28]. Therefore, it was not possible to prevent loss of phenolic compounds after drying. 
The total content of free phenolic acids also increased with the increase of the functional additive content in the pasta samples, reaching values of 26.671, 28.359, 29.525, 32.503, 34.097, 36.153, and $38.876 \mu \mathrm{g} / \mathrm{g}$ of dry matter, respectively, for the control without addition and samples enriched with the addition of $2.5 \%, 5.0 \%, 7.5 \%, 10.0 \%, 12.5 \%$, and $15.0 \%$ of fruit.

The obtained test results thus showed that the antioxidant activity of pasta was positively correlated with the amount of added prickly pear fruit, and the content of free phenolic acids and the sum of polyphenols. Pearson's coefficients, indicating the relationship between functional additive, polyphenols, free phenolic acid content and antioxidant activity (measured after $10 \mathrm{~min}$ ), are presented in Table 3. Herein, it can be seen that very high positive correlations were established between the applied fruit addition and the polyphenol content $(\mathrm{r}=0.994)$ and between the amount of enrichment additive and the content of free phenolic acids $(r=0.995)$. Of note, previous research has shown that aglycones have a higher antioxidant activity than glycosidic forms or those connected by different types of bonds [25,32]. The antioxidant activity of polyphenols is also dependent on the number of hydroxyl groups in the molecule and can be enhanced by spherical effects, as well as by synergistic and antagonistic interactions of the compounds present in the matrix and in the extracts. Thus, an increase in the content of polyphenolic compounds entails an increase in antioxidant properties.

\section{Conclusions}

The presented study indicates that Opuntia fruit (prickly pear) is a rich source of phenolic compounds, especially the benzoic acid derivatives: protocatechuic, syryngic, 4-OH-benzoic, vanilic, gentisic, salicylic, as well as the cinnamic acid derivatives: caffeic, trans-sinapic, and cis-sinapic, $p$-coumaric, ferulic, isoferulic, $m$-coumaric and 3,4-dimetoxycinnamic. Due to their high antioxidant potential, such fruit can be used as a valuable food additive. In our study, a gluten-free pasta based on a rice-field bean blend was prepared with the addition of $2.5-15.0 \%$ of prickly pear fruits. This fortified pasta showed high content of phenolic compounds, especially at levels of $12.5 \%$ and $15.0 \%$ of the additive. Herein, the maximum scavenging ability of DPPH free radical by all pasta extracts was obtained after $10 \mathrm{~min}$ and the increased amount of functional additive brought about an increase in antioxidant properties. Extracts from pasta with the largest (15.0\%) addition of prickly fruit showed the greatest antioxidant properties. Our research has demonstrated that innovative gluten-free pasta supplemented with Opuntia fruits is a good source of natural antioxidants, and thus, can improve the quality of health and life of coeliac consumers. In the future, products such as this can enrich the range of gluten-free products that have entered the ranks of functional foods.

Author Contributions: Conceptualization, A.O., A.W. and A.D.; methodology, A.O. and A.D.; validation, A.W. and A.O.; formal analysis A.O. and T.O.; investigation, T.O. and A.M.; resources, A.O. and A.D.; data curation, A.O., A.W., T.O. and A.M.; writing-original draft preparation, A.O. and A.W.; writing-review and editing, A.W., T.O. and E.M.-M.; visualization, A.O.; supervision, A.W. All authors have read and agreed to the published version of the manuscript.

Funding: This research received no external funding

Conflicts of Interest: The authors declare no conflict of interest.

\section{References}

1. Bayar, N.; Kriaa, M.; Kammoun, R. Extraction and characterization of three polysaccharides extracted from Opuntia ficus indica cladodes. Int. J. Biol. Macromol. 2016, 92, 441-450. [CrossRef] [PubMed]

2. Adli, B.; Boutekrabt, A.; Touati, M.; Bakria, T.; Touati, A.; Bezini, E. Phenotypic diversity of Opuntia ficus indica (L.) Mill. in the Algerian steppe. S. Afr. J. Bot. 2017, 109, 66-74. [CrossRef]

3. Russel, C.E.; Felker, P. The prickley pear (Opuntia spp., Cactaceae): A source of human and animal food in semi-arid regions. Econ. Bot. 1987, 41, 433-445. [CrossRef]

4. Farag, M.A.; Maamoun, A.A.; Ehrlich, A.; Fahmy, S.; Wesjohann, L.A. Assessment of sensory metabolites distribution in cactus Opuntia ficus-indica fruit cultivars using UV fingerprinting and GC/MS profiling techniques. LWT-Food Sci. Tech. 2017, 80, 145-154. [CrossRef] 
5. Cieślik, E.; Cieślik, I.; Bartyzel, K. Wartość odżywcza i właściwości prozdrowotne opuncji figowej (Opuntia ficus-indica Mill.). Postępy Fitoterapii 2016, 17, 213-217.

6. Berrabah, H.; Taibi, K.; Ait Abderrahim, L.; Boussaid, M. Phytochemical composition and antioxidant properties of prickly pear (Opuntia ficus-indica L.) flowers from the Algerian germplasm. Food Meas. 2019, 13, 1166-1174. [CrossRef]

7. Yeddes, N.; Chérif, J.K.; Guyot, S.; Sotin, H.; Ayadi, M.T. Comparative study of antioxidant power, polyphenols, flavonoids and betacyanins of the peel and pulp of three tunisian Opuntia forms. Antioxidants 2013, 2, 37-51. [CrossRef]

8. Khatabi, O.; Hanine, H.; Elothmani, D.; Hasib, A. Extraction and determination of polyphenols and betalain pigments in the Moroccan Prickly pear fruits (Opuntia ficus indica). Arab. J. Chem. 2016, 9, S278-S281. [CrossRef]

9. Gouws, C.A.; Georgousopoulou, E.N.; Mellor, D.D.; McKune, A.; Naumovski, N. Effects of the consumption of prickly pear cacti (Opuntia spp.) and its products on blood glucose levels and insulin: A systematic review. Medicina (Lithuania) 2019, 55, 138. [CrossRef]

10. Onakpoya, I.J.; O'Sullivan, J.; Heneghan, C.J. The effect of cactus pear (Opuntia ficus-indica) on body weight and cardiovascular risk factors: A systematic review and meta-analysis of randomized clinical trials. Nutrition 2015, 31, 640-646. [CrossRef]

11. Mata, A.; Ferreira, J.P.; Semedo, C.; Serra, T.; Duarte, C.M.M.; Bronze, M.R. Contribution to the characterization of Opuntia spp. juices by LC-DAD-ESI-MS/MS. Food Chem. 2016, 210, 558-565. [CrossRef] [PubMed]

12. Zenteno-Ramírez, G.; Juárez-Flores, B.I.; Aguirre-Rivera, J.R.; Monreal-Montes, M.; Mérida García, J.; Pérez Serratosa, M.; Varo Santos, M.Á.; Ortiz Pérez, M.D.; Rendón-Huerta, J.A. Juices of prickly pear fruits (Opuntia spp.) as functional foods. Ital. J. Food Sci. 2018, 30, 614-627.

13. Jiménez-Aguilar, D.M.; Escobedo-Avellaneda, Z.; Martín-Belloso, O.; Gutiérrez-Uribe, J.; Valdez-Fragoso, A.; García-García, R.; Torres, J.A.; Welti-Chanes, J. Effect of high hydrostatic pressure on the content of phytochemical compounds and antioxidant activity of prickly pears (Opuntia ficus-indica) beverages. Food Eng. Rev. 2015, 7, 198-208. [CrossRef]

14. Salehi, E.; Emam-Djomeh, Z.; Askari, G.; Fathi, M. Opuntia ficus indica fruit gum: Extraction, characterization, antioxidant activity and functional properties. Carb. Polym. 2019, 206, 565-572. [CrossRef] [PubMed]

15. Bustos, E.O. Alcoholic beverage from Chilean Opuntia ficus indica. Am. J. Enol. Vitic. 1981, 32, $228-229$.

16. Guevara-Arauza, J.C.; Órnelas Paz, J.D.J.; Mendoza, S.R.; Guerra, R.E.S.; Paz Maldonado, L.M.T.; González, D.J.P. Biofunctional activity of tortillas and bars enhanced with nopal. Preliminary assessment of functional effect after intake on the oxidative status in healthy volunteers. Chem. Cent. J. 2011, 5, 10. [CrossRef] [PubMed]

17. Aiello, A.; Di Bona, D.; Candore, G.; Carru, C.; Zinellu, A.; Di Miceli, G.; Nicosia, A.; Gambino, C.M.; Ruisi, P.; Caruso, C.; et al. Targeting aging with functional food: Pasta with opuntia single-arm pilot study. Rejuve. Res. 2018, 21, 249-256. [CrossRef]

18. Bouasla, A.; Wójtowicz, A.; Zidoune, M.N.; Olech, M.; Nowak, R.; Mitrus, M.; Oniszczuk, A. Gluten-free precooked rice-yellow pea pasta: Effect of extrusion-cooking conditions on phenolic acids composition, selected properties and microstructure. J. Food Sci. 2016, 81, C1070-C1079. [CrossRef]

19. Dib, A.; Kasprzak, K.; Wójtowicz, A.; Benatallah, L.; Waksmundzka-Hajnos, M.; Zidoune, M.N.; Oniszczuk, T.; Karakuła-Juchnowicz, H.; Oniszczuk, A. The effect of pomegranate seed powder addition on radical scavenging activity determined by TLC-DPPH test and selected properties of gluten-free pasta. J. Liq. Chromatogr. Relat. Technol. 2018, 41,364-372. [CrossRef]

20. Oniszczuk, A.; Waksmundzka-Hajnos, M.; Skalicka-Woźniak, K.; Głowniak, K. Comparison of matrix-solid phase dispersion and liquid-solid extraction connected with solid-phase extraction in the quantification of selected furanocoumarins from fruits of Heracleum leskovii by high performance liquid chromatography. Ind. Crops Prod. 2013, 50, 131-136. [CrossRef]

21. Oniszczuk, T.; Widelska, G.; Oniszczuk, A.; Kasprzak, K.; Wójtowicz, A.; Olech, M.; Nowak, R.K.; Wojtunik-Kulesza, K.; Jóźwiak, G.; Waksmundzka-Hajnos, M. Influence of production parameters on the content of polyphenolic compounds in extruded porridge enriched with chokeberry fruit (Aronia melanocarpa (Michx.) Elliott). Open Chem. 2019, 17, 166-176. [CrossRef] 
22. Oniszczuk, A.; Oniszczuk, T.; Wójtowicz, A.; Wojtunik, K.; Kwaśniewska, A.; Waksmundzka-Hajnos, M. Radical scavenging activity of extruded corn gruels with addition of linden inflorescence. Open Chem. 2015, 13, 1101-1107. [CrossRef]

23. Moussa-Ayoub, T.E.; El-Samahy, S.K.; Rohn, S.; Kroh, L.W. Flavonols, betacyanins content and antioxidant activity of Cactus Opuntia macrorhiza fruits. Food Res. Int. 2011, 44, 2169-2174. [CrossRef]

24. Maatoui, B.S.; Hmyene, A.; Hilali, S. Activités anti-radiculaires d'extraits de jus de fruits du figuier de Barbarie (Opuntia ficus indica). Leban. Sci. J. 2006, 7, 3-8.

25. Karamać, M.; Kosińska, A.; Pegg, R.B. Comparison of radical-scavenging activities for selected phenolic acids. Pol. J. Food Nutr. Sci. 2005, 55, 165-170.

26. Kuti, J.O. Antioxidant compounds from four Opuntia cactus pear fruit varieties. Food Chem. 2004, 85, 527-533. [CrossRef]

27. Gentile, C.; Tesoriere, L.; Allegra, M.; Livrea, M.A.; D'Alessio, P. Antioxidant betalains from cactus pear (Opuntia ficus indica) inhibit endothelial ICAM-1 expression. Ann. N. Y. Acad. Sci. 2004, 1028, 481-486. [CrossRef]

28. Bernardino-Nicanor, A.; Montañez-Soto, J.L.; de los Ángeles Vivar-Vera, M.; Juárez-Goiz, J.M.; Acosta-García, G.; González-Cruz, L. Effect of drying on the antioxidant capacity and concentration of phenolic compounds in different parts of the Erythrina americana tree. Bioresources 2016, 11, 9741-9755. [CrossRef]

29. Patrón-Vázquez, J.; Baas-Dzul, L.; Medina-Torres, N.; Ayora-Talavera, T.; Sánchez-Contreras, Á.; García-Cruz, U.; Pacheco, N. The Effect of drying temperature on the phenolic content and functional behavior of flours obtained from lemon wastes. Agronomy 2019, 9, 474. [CrossRef]

30. Esparza-Martínez, F.J.; Miranda-López, R.; Guzman-Maldonado, S.H. Effect of air-drying temperature on extractable and non-extractable phenolics and antioxidant capacity of lime wastes. Ind. Crop. Prod. 2016, 84, 1-6. [CrossRef]

31. Multari, S.; Marsol-Vall, A.; Keskitalo, M.; Yang, B.; Suomela, J.P. Effects of different drying temperatures on the content of phenolic compounds and carotenoids in quinoa seeds (Chenopodium quinoa) from Finland. J. Food Compos. Anal. 2018, 72, 75-82. [CrossRef]

32. Madhujith, T.; Izydorczyk, M.; Shahidi, F. Antioxidant properties of pearled barley fractions. J. Agric. Food Chem. 2006, 54, 3283-3289. [CrossRef] [PubMed]

Sample Availability: Samples of the gluten-free pasta are available from the authors.

(C) 2020 by the authors. Licensee MDPI, Basel, Switzerland. This article is an open access article distributed under the terms and conditions of the Creative Commons Attribution (CC BY) license (http://creativecommons.org/licenses/by/4.0/). 